\begin{tabular}{|ccc|}
\hline & ANNALES INSTITUTI SLAVICI \\
& UnIVERSITATIS DEBRECENIENSIS & \\
SLAVICA XLVII & 2018 & DEBRECEN \\
\hline
\end{tabular}

Дмитрий МАЗАЛЕВСКИЙ

\title{
РОЛЬ ЦЕНЗОРА НИКОЛАЯ РАТЫНСКОГО В РОССИЙСКОЙ ПУБЛИЦИСТИКЕ ВТОРОЙ ПОЛОВИНЫ XIX ВЕКА
}

\section{Censor Nikolay Ratynsky's Role in Russian Journalism of the Second Half of the $19^{\text {th }}$ Century}

Recently, the political climate in Russia has caused the question of censorship to become an increasingly relevant issue, the history of which is necessary to explore and understand. The prevailing view regarding censorship is that it is a tool used to suppress the freedom of speech by stifling the writer's thoughts. However, there were some eminent censors such as the poet Fyodor Tyutchev and the writer Ivan Goncharov. In this regard, it has become commont to consider censorship isolated from any moral categories and interpret $\mathrm{g}$ it only as a professional activity. In this context, the work of the censor Nikolai Ratynsky is of particular interest to us. Until now, little has been published on his influence as a censor on the writers of his time on the high professional level of his work in this capacity. Most of the corrections Ratynsky made were valid and justified by the political situation in the Russian Empire. $\mathrm{He}$ himself is further proof that, along with Tyutchev and Goncharov, there were honorable and qualified men among the censors of the time. All this allows us to claim that it is necessary to objectively consider and study the work of censors and ignor preconceptions and stereotypes that are usually associated with the word censor.

Keywords: censorship, Ratynsky, Nekrasov, Saltykov-Shchedrin, Dostoevsky, a Writer's Diary

Публицистическая и литературная обстановка в России во второй половине XIX века изучена довольно подробно: этот отрезок времени пестрит такими именами, как Ф. Тютчев, И. Гончаров, Н. Некрасов, тройка революционеров-демократов Н. Чернышевского, Н. Добролюбова и Д. Писарева, М. Салтыков-Щедрин, Л. Толстой, Ф. Достоевский и другие. Эти люди считаются непревзойденными мастерами своего дела, гениями, талантливо выражавших свои мысли вопреки суровой царской цензуре. Вместе с тем, в научной среде довольно редко делается акцент на противоположную сторону, то есть на персону самого цензора. В центре внимания настоящей статьи - личность Н.А. Ратынского, активно влиявшего на творчество П. Вяземского, Ф. Достоевского и М. Салтыкова-Щедрина, который руководствовался исключительно профессиональными побуждениями и даже стремился поддержать этих литераторов и помочь им.

До настоящего времени деятельность цензора Н.А. Ратынского не подвергалась должному изучению. Внимание ему уделяется лишь в статье известного достоевсковеда И.Л. Волгина «Достоевский и царская цензура: К истории издания «Дневника писателя», опубликованная в журнале «Русская Литература» в 1970 году. В конце своей статьи исследователь сам признает, что этот вопрос требует дополнительного изучения. Кроме Волгина к личности Ратынского 
в контексте исследования его как цензора наука не обращается. Между тем, проблема профессионального, непредвзятого отношения к некоторым надзирательным институтам имперской России становится все актуальнее, что подтверждает высказывание А. Рейтблата в монографии «Фаддей Венедиктович Булгарин: идеолог, журналист, консультант секретной полиции: Статьи и материалы»: «На мой взгляд, настало время перейти от моральных оценок (типа порядочно/непорядочно) к историко-социологической интерпретации намерений и поступков людей николаевской эпохи $<\ldots>$, и в частности к осознанию неизбежности в подобных условиях симбиоза журналистики и секретной полиции (опыт советского времени в этом отношении еще более показателен)» [РЕЙтБЛАТ 2016: 113]. Несмотря на то, что речь в отрывке идет о Булгарине, мы можем перенести пафос высказывания этого современного ученого и на более поздние десятилетия, например, 1860-1870-е, имея в виду и случай $\mathrm{H}$. Ратынского, да и других цензоров. Время перейти "от моральных оценок к историко-социологической интерпретации" пришло и для оценки этих деятелей, профессионалов российской цензуры. В свою очередь, известный литературовед и библиограф Е.Б. Белодубровский считает, что «...имя Николая Антоновича Ратынского достойно отдельной статьи, так как оно было в течение нескольких десятилетий знакомо многим русским писателям. Н. А. Ратынский пользовался известной репутацией и как цензор, и как литератор, историк и библиограф» [БЕЛОДУБРОВСКИй 1985: 238].

\section{Ратынский и окружение}

О Николае Антоновиче Ратынском известно не так много. Известно, что он родился в один год с Ф.М. Достоевским - в 1821 году (по другим данным, в 1820). Являлся кандидатом Московского Государственного Университета степень «кандидат» являлась низшей ступенью в иерархии «кандидат - магистр - доктор» и присваивалась тем студентам, что окончили курс университета «на отлично» и подготовили, а затем и защитили письменную работу на выбранную ими тему; степень давала право на чин 10 класса в Табели о рангах - коллежский секретарь. В 1849 году на всю страну прогремело дело Петрашевского, которое стало известным, в том числе, по причине участия в нем молодого Достоевского, который по итогам следствия, как известно, был отправлен в Сибирь на каторжные работы. По подозрениям в связях с петрашевцами привлекался и Николай Ратынский, однако ему повезло больше: подозрения были сняты и молодой литератор (а первые его произведения в «Отечественных записках» датированы 1844 годом) был отпущен. По некой иронии судьбы своим делом жизни он выбрал государственную работу и служил при канцелярии Петербургского военного губернатора и в Министерстве внутренних дел, а с 11 апреля 1872 года был назначен цензором Санкт-Петербургского цензурного комитета. И вновь судьба сводит его с Достоевским: на время 1876-1877 годов приходится его цензорство и кураторство над «Дневником писателя» вернувшегося из ссылки литератора. С 16 апреля 1881 года, спустя 
три месяца после смерти Достоевского, Ратынский был назначен членом Совета Главного управления по делам печати. Известны некоторые публицистические произведения Ратынского: статья «Иезуиты» в «Отечественных записках» за 1844 год, «Памятная книжка Орловской губернии на 1860 г». (Орел, 1860), «Эпиграммы, шутки и послания Д.Т. Ленского» («Русская старина» 1880, ч. XXIX); «Арифметика, сиречь наука числительная» («Памятники древней письменности», 1881, выпуск II), «Двор и правительство в России сто лет тому назад» («Русский архив», 1886, кн. 2). Необходимо уточнить, что Н.А. Ратынский являлся действительным членом Орловского губернского статистического комитета, и именно ему местный губернатор поручил составление первой «Памятной книжки Орловской губернии», содержащей сведения по статистике, истории и административному устройству губернии. Ольга Сафонович - одна из дочерей Валериана Сафоновича, губернатора Орловской губернии и чиновника министерства внутренних дел - вспоминает, что помещики Орловской губернии считали ее отца убежденным «крепостником», не отвечающим либеральным вызовам современности. Исходило это мнение, по предположению Ольги, в том числе от Н.А. Ратынского - «умнейшего, но коварного помещика, имевшего знакомства в Петербурге и - посредством супруги - связь с императрицей Марией Александровной, который мог сказать что-нибудь очень веское о Сафоновиче и тем самым приблизить его отставку» [ТРОХИНА и др. 1998: 128].

О его отношении к литераторству весьма тонко отозвался А. Фет в своих «Воспоминаниях»: «Покойный, в свое время известный литературному миру, Ник. Ант. Ратынский, рассказавши какой-либо забавный анекдот из действительной жизни, нередко прибавлял: «оно, положим, было не совсем так, но так это надо рассказывать». Этими словами ясно определяется добросовестное отношение к художественному повествованию» [ФЕТ 1983: 357]. Знаем мы и дату смерти Ратынского - 22 сентября 1887 года - об этом пишет его одногруппник по Московскому Дворянскому институту Михаил Салтыков-Щедрин в письме к известному публицисту, мемуаристу и врачу Н.А. Белоголовому: «[Ратынский] почувствовал себя дурно на углу Литейной и Невского, нанял извозчика, но едва доехал до дому, как у него в швейцарской отнялись руки, ноги и язык. Сутки, однако ж, после этого прожил, но сознавал ли чтонибудь - неизвестно» [САЛТЫКОВ-ЩЕДРИН 1977: 376].

Более детальную информацию о Николае Ратынском ввиду отсутствия однозначных источников мы вынуждены искать в письмах и мемуарах его окружения. Так, яркую характеристику о нем мы находим в мемуарах литератора Е.Н. Опочинина. Он отзывается о Ратынском как об образованном, «добром и приветливом старичке», отмечая его чувство юмора. Придя к генералу Хрущеву и увидев, что у того новый работник, не знавший его в лицо, Ратынский представился «бедным орловским помещиком», прося аудиенции. Естественно, занятой генерал отказал бедному помещику из-за нехватки времени, а то и нежелания. Ратынский попросил слугу доложить генералу, что им движет «крайняя необходимость» и от этой просьбы зависит вся его жизнь. Лакей был крайне раздражен на Ратынского, но, вернувшись второй раз с отказом, 
выплеснуть на него всю свою грубость не посмел: Н. Ратынский в его отсутствие снял пальто и предстал перед ним со звездой на груди и красной лентой через плечо. Вот как Опочинин описывает эту ситуацию: «Слуга окончательно оторопел, когда Н.А. протянул ему свою карточку и сказал: - Пойди, любезный, и доложи господину Хрущову, что тайный советник Ратынский желает его видеть. Слуга опрометью бросился докладывать, и через секунду в переднюю влетел, потеряв всю свою важность, И.П. Хрущов со словами: - Ваше превосходительство! Что же это вы со мною делаете?».

В тех же воспоминаниях Опочинин называет Ратынского «неистощимым рассказчиком и великим юмористом», который приводил всех в восторг своими повествованиями и знаниями русской литературы и особенно поэзии, которой Николай Антонович, по собственному признанию, с юности посвящал свои досуги: «Зато и знал он всех лучших наших поэтов, начиная с Пушкина, наизусть и прекрасно читал их произведения без малейшей запинки. <..> ...в декламации Ратынского слышались грозные пророческие стихи Хомякова, гармонические антологии Майкова и Щербины, а иногда остроты и эпиграммы Пушкина, его шутливого приятеля Соболевского и других памятных людей пушкинского времени. Философские задумчивые строфы Ф.И. Тютчева чередовались с былинными стихами А.К. Толстого» [ОПОчинин 1928].

Итак, в этой обстоятельной и подробной характеристике Ратынский предстает перед нами уже на склоне лет как человек, прекрасно разбирающийся в литературе, древности, прекрасно подкованный в эрудиции и кругозоре, обладающий потрясающей памятью, чувством юмора, глубиной и точностью мысли. Все это важно нам для правильного понимания личности Ратынского, чтобы трактовать его поступки и действия в тех или иных ситуациях. О Ратынском, как о человеке, не лишенном чувства юмора, вспоминает и все тот же А. Фет в своих «Воспоминаниях»: «Между обычными посетителями григорьевского мезонина стал появляться неистощимый рассказчик и юморист, однокурсник и товарищ Григорьева Ник Антонович Ратынский, сын помещика Орловской губернии, Дмитровского уезда; он, кажется, не получал от отца никакого содержания и вынужден был давать уроки» [ФЕТ 1983: 114]. Таким образом, мы делаем вывод, что Н. Ратынский занимал довольно высокое положение по государственной службе и пользовался высочайшим авторитетом в литературных кругах. Наиболее интересны его взаимоотношения с тремя знаковыми фигурами русской публицистики второй половины XIX века: Н.А. Некрасовым, М.Е. Салтыковым-Щедриным и Ф.М. Достоевским. 


\section{Ратынский и Некрасов}

Достаточно близок с Ратынским был известный поэт, публицист и редактор «Современника» и «Отечественных записок» Н.А. Некрасов. А.А. Демченко в своей статье «Отечественные записки» и цензура в 1840-1880-х гг.» выдвигает мнение о том, что редактор «Отечественных записок» Н. Некрасов мастерски пользовался либеральными настроениями некоторых цензоров для личной и профессиональной выгоды: «Смягчению иных приговоров в течение ряда лет содействовали цензоры В.М. Лазаревский, А.Г. Петров, Н.А. Ратынский» [ДЕмЧЕНКО 2012: 121]. Это соотносится с утверждением некоторых исследователей о том, что Некрасов, якобы, намеренно втирался в доверие к нужным ему работникам цензурного комитета и поддерживал искусственно-дружеские отношения с ними ради корыстных целей. Известны так называемые «Некрасовские четверги» - званые обеды, которые устраивал редактор «Отечественных записок» в компании «нужных» ему цензоров. Это подтверждается запиской Некрасова к цензору Петербургского Цензурного Комитета Н.А. Ратынскому, впервые опубликованной в журнале «Русская литература» (1965, № 3) Б. Бессоновым. Вот ее текст: «Я продолжаю хворать и сидеть дома. К сожалению, Унковский сегодня быть не может, но Ераков будет. Приходите, отец, к 5-ти ч<асам $>$. Еда будет самая легкая. Четверг». Текст написан карандашом на визитной карточке Некрасова, вложенной в маленький, почти в размер визитки, конверт, на котором тем же карандашом написано: «Его Превосходительству Николаю Антоновичу Ратынско<му $>$ ». Первое же упоминание о Ратынском в переписке Некрасова считается письмо к поэту публициста Г.З. Елисеева: «...На днях видел только Ратынского, он, как и всегда, мил и любезен...» [НЕКРАСОВ 1949: 258]. Принимая во внимание добрый отзыв о цензоре со стороны близкого друга редактора «Отечественных записок», а также, не забывая два других имени в приведенной выше записке (А.М. Унковский - общественный деятель и адвокат и А.Н. Ераков - известный инженер, являлись близкими людьми к Некрасову), Белодубровский делает предположение, что тем самым смертельно больной поэт пытается «утвердить прежний характер традиционных некрасовских "четвергов"». Посему можно заключить, что Ратынский также состоял в довольно дружеских отношениях с Некрасовым. Кроме того, это подтверждает тот факт, что Николай Антонович был единственным из цензоров, входящих в узкий круг близких людей Некрасова, кто после его смерти первыми получили доступ к первому посмертному изданию стихотворений покойного поэта. Наряду с Ратынским в этот список входили уже упомянутые А.М. Унковский и А.Н. Ераков, а также знаменитый юрист и адвокат А.Ф. Кони, публицисты и переводчики Н. Курочкин и А. Плещеев и известные врачи С.П. Боткин и Н.А. Белоголовый. 


\section{Ратынский и Салтыков-Щедрин}

10 мая 1880 года М. Салтыков пишет письмо Г.З. Елисееву, в котором подробно рассказывает о своем визите к начальнику Главного управления по делам печати Н.С. Абазе по обвинению журнала «Отечественные записки» в социалистическом направлении. В качестве некоторого отступления, которое, однако, органично вписывается в тематику нашей статьи, стоит отметить, что Н. Абаза получил характеристику от Щедрина как человек либеральный. Абаза же сообщил Щедрину, что спас журнал от второго предупреждения после очерка последнего «Не весьма давно (Осенние воспоминания)», что еще раз подтверждает нашу мысль о том, что не все цензоры XIX века были душителями свободы слова. Однако же вернемся к Ратынскому. Щедрин в том же письме пишет: «Доклад об «Отеч<ественных> зап<исках>» делал Скуратов по внушению Валуева. Что же касается до Стремоухова, то оказывается, что Ратынский все соврал» [САЛТыКОВ-ЩЕДРИН 1880]. Что же мог «наврать» Ратынский? Из воспоминаний сына Салтыкова-Щедрина мы узнаем, что Ратынский был частым гостем в их доме: «Частенько заходил также к нам цензор Ратынский, человек далеко некрасивый и немолодой. Приходил он по вечерам и выпивал целый графин красного вина. Его визиты имели характер весьма деловой, т. к. он информировал моего отца о том, что происходит в цензурном комитете. Эти сведения для моего отца, одного из редакторов «Отечественных Записок», были весьма ценны, так как, зная о том, какие влияния преобладают в комитете, он имел возможность ограждать свой любимый журнал от произвола цензуры, которая, как известно, в восьмидесятых годах прошлого столетия, пребольно кусалась» [САЛтыКОВ-ЩЕДРИН 1923: 79]. Эта характеристика не позволяет точно судить о характере взаимоотношений двух литераторов. С одной стороны, Ратынский и Салтыков знакомы с юности - как уже было сказано, они являлись товарищами по Московскому Дворянскому институту. Известно, что Ратынский являлся одним из доверенных лиц М. СалтыковаЩедрина по Цензурному комитету. Известно также, что цензор хлопотал о разрешении конфликта между ним и начальником Главного управления по делам печати В.В. Григорьевым. Конфликт заключался в следующем. Щедрин в письме Некрасову пишет, что его «Экскурсии» получили одобрение у Ратынского и ожидали лишь официального подтверждения у Григорьева. Однако, когда Салтыков прибыл к последнему, тот встретил его довольно холодно и грубо, отказав в печати: «Принял он меня не только холодно, но почти неприязненно, даже не посадил. Хотел ли он поломаться надо мной, но первым вопросом его было следующее: Вы в каком журнале участвуете? Хотя Ратынский и уверял меня, что он уже читал «Экскурсии» в первой редакции, но он и виду не подал, а когда я заикнулся о том, что вот, дескать, цензура встретила год тому назад затруднения, а ныне я переделал, и желал бы, чтоб ваше превосходит<ельство> удостоили прочесть, то он прямо объявил: это не мое делоc, на это есть цензора. Одним словом, свидание вряд ли продолжалось и минуту, но, несмотря на это, мне показалось, что на меня целый час плевали» 
[САЛТЫКОВ-ЩЕДРИН 1976: 14]. Обескураженный Щедрин доложил об этом Ратынскому. Об успешном разрешении конфликта мы узнаем уже из письма Елисеева Некрасову от 27 сентября 1876 года: «На днях видел только Ратынского; он, как и всегда, мил и любезен. Он возил Салтыкова к Григорьеву по поводу известной Вам истории. Григорьев принял его с подобающим почтением и принес все возможные извинения. Салтыков, видимо, остался доволен приемом, говорит, по крайней мере, что теперь Григорьев пропустит ему все, что бы он ни написал» [НЕКРАСОВ 1949: 258]. Из этого письма мы заключаем, что Ратынский пользовался непререкаемым авторитетом в Цензурном комитете, раз одно его присутствие заставило В. Григорьева кардинально изменить свое поведение, должным образом принять Салтыкова-Щедрина как подопечного и подзащитного Ратынского и принести ему свои извинения. Подобная отзывчивость вполне может быть следствием давнего знакомства двух литераторов. С другой стороны, мы не находим ни одного свидетельства благодарности Щедрина к Ратынскому или доброго о нем слова. В упомянутом уже выше письме к Н. Белоголовому Щедрин довольно прохладно, отстраненно и официозно пишет о смерти своего своеобразного покровителя: «Покойный был мне товарищем по Московскому Дворянскому институту и в последнее время часто меня навещал. Он крайне был для меня полезен в цензурном отношении, ибо служил в Совете книгопечатания членом» [САЛтыКОВЩЕДРИн 1977: 376]. Формулировка «был для меня крайне полезен» создает впечатление о Щедрине как о корыстном человеке, общавшимся с Ратынским исключительно ввиду его «полезности». Для сравнения, вот как он в том же самом письме пишет о смерти некоего студента Иваницкого, пришедшейся на те же дни, что и смерть Николая Антоновича: «На даче нынешним летом меня навещал студент академии Иваницкий, и мы так дружески сошлись, что он даже проводил меня с дачи в Петербург. Так как он обещал зайти ко мне, то я два раза писал к нему напоминательные письма, спрашивал о причине перемены, случившейся в наших отношениях, но ни на одно письмо ответа не получил. Сегодня утром пришел его товарищ и объявил, что вчера он умер от апоплексии. А не отвечал мне, потому что для него настала пора запоя. Ужасно мне жаль этого бедного молодого человека, который так тепло и сердечно отнесся ко мне» [САЛТЫКОВ-ЩЕДРИН 1977: 376]. Почему по отношению к студенту он использует эпитеты «бедный», «дружески сошлись», «тепло и сердечно отнесся ко мне», а к цензору, часто посещавшего его и выручавших в трудных ситуациях, обращается канцелярски-официозно «покойный»? Конечно, по прошествии нескольких веков представляется практически невозможным судить о взаимоотношениях людей, живших так давно и не все свои эмоции выражавших в частных письмах, однако гипотеза о меркантильном отношении Щедрина к Ратынскому представляется нам несколько более близкой к истине. Возвращаясь к упомянутому письму Щедрина к Некрасову о походе первого к Абазе, стоит отметить, что сам Салтыков отозвался о Ратынском так же прохладно, сказав, что «ничего о нем не думает». Возможно, это было улов- 
кой и намеренным желанием не распространяться о личности Ратынского перед Абазой, тем более, что сам Щедрин заподозрил, что вопрос этот может быть подстроен для выяснения отношения Салтыкова к Ратынскому: «При этом свидании присутствовал и Ратынский (случайно), но замечательно, что когда Ратынский вышел, то Абаза обратился ко мне: ну, а об этом господине что Вы думаете?» [САЛТЫКОВ-ЩЕДРИН 1880]. Стоит отметить, что ситуация эта произошла спустя четыре года после вмешательства Ратынского в конфликт Щедрина с Григорьевым. Что же касается того замечания Салтыкова, что «Ратынский все соврал», то факт вранья остается скрыт для нас туманом истории. Однако, возможно, именно в этом кроется причина прохладного отношения Щедрина к Ратынскому, который принимал его у себя дома и выслушивал последние новости Цензурного комитета, однако, вполне вероятно, относился с подозрением и недоверием.

\section{Ратынский и Достоевский}

Наиболее изученным периодом жизни Ратынского является тот его отрезок, когда он цензурировал моножурнал Ф.М. Достоевского «Дневник писателя». Интересно проследить сами отношения Достоевского с цензурой, еще до вступления Ратынского в свои обязанности.

Большинство журналов 1870-ых годов не имели предварительной цензуры, но просматривались цензорами уже после выхода журнала в свет. Однако «Дневник писателя» был исключением и проходил проверку цензора до опубликования. Еще в 60-ые годы Достоевский не имел права официально возглавлять журналы «Время» и «Эпоха», издаваемые им с братом. В связи с этим неудивительно, что Достоевский, вплоть до конца своей жизни находившийся под негласным надзором полиции, сам стал инициатором предварительной цензуры своего «Дневника писателя», вместе с тем имея несколько иных на то причин. Во-первых, предварительная цензура в определенном плане снимала с него немалую долю ответственности и обеспечивало безопасность и покой. Во-вторых, по свидетельству М.А. Александрова, метранпажа типографии, где печатался «Дневник писателя», Ф. Достоевский сам заявлял, что «выходя без цензора, надо самому быть цензором для того, чтобы цензурно выйти, а он по опыту знает, как трудно быть цензором собственных произведений» [ДоСтОЕВСКИй 1994: 413]. Кроме того, когда в 1877 году Главное управление по делам печати сочло, что «Дневник писателя» может отныне выходить без предварительной цензуры, Достоевский принял решение не менять установившегося порядка вещей, т.к. действующий способ издания был для него более удобен. Самоцензура отнимала бы больше сил и финансов (цензурные правки вынуждали перепечатывать готовую книгу), увеличила бы ответственность издателя, а также ударила бы по регулярности выхода издания в начале месяца, что было особенно важно для Достоевского: «Цензор Скуратов не принимается цензуровать "Дневника писателя", не получив на то предписания от Комитета, а Комитет не дает этого предписания, заставляя печатать 
без предварительной цензуры, чего никак не желает Федор Михайлович из-за проволочки восьмидневного лежания выпуска в Комиссии» [ДостоЕВСКИй 1877]. 27 декабря 1875 года Достоевский получает разрешение на издание собственного журнала от начальника Главного управления по делам печати В. Григорьева (того самого, что уже знаком нам из конфликта с Щедриным), получить которое было нелегко ввиду того, что писатель все еще числился как бывший политический преступник. Этому в немалой степени способствовали приятельские личные отношения между Достоевским и Григорьевым. По воспоминаниям второй жены писателя, Анны Григорьевны Достоевской, зимой 1872-1873 годов «Федор Михайлович имел случай встретиться со многими лицами из ученого мира; с одним из них, В.В. Григорьевым (востоковедом), Федор Михайлович с особенным удовольствием беседовал» [ДостОЕВСКАЯ 1987: 213]. Их сближению благоприятствовали славянофильские убеждения Григорьева, а также интерес Достоевского к Востоку и восточной миссии России. Полноценное разрешение на издание журнала Достоевский получает 31 декабря: «Г. министр внутренних дел изволил разрешить отставному подпоручику Федору Достоевскому издавать сочинение его «Дневник писателя» ежемесячными выпусками и открыть на издание оного подписку: за годовое издание 2 р. Исправляющий должность начальника Главного управления по делам печати В. Григорьев. Правитель дел Ю. Богушевич». На документе имеется пометка о назначении куратора: «Цензурирование поручено г. цензору Ратынскому...».

Воспоминания М. Александрова о Ратынском и его отношениях с Достоевским носят двойственный характер: «...цензор Николай Антонович Ратынский, цензуровавший «Дневник», - пишет Александров, - почти все время его издания, говаривал Федору Михайловичу в шутку, что он не цензурует его, а только поправляет слог. Это значило, что иногда, вместо того, чтобы вымарывать что-либо неудобное цензорскою властью, он заменял одно слово другим и тем смягчал выражение фразы» [ДостОЕВСКИй 1994: 421].

Однако далее Александров сообщает: «...Федору Михайловичу, как автору, доводилось, хотя и редко, испытывать неприятности по поводу более или менее крупных авторских помарок. Бывало и так, что цензором запрещалась целая статья, и тогда начинались для Федора Михайловича хлопоты отстаивания запрещенной статьи: он ездил к цензору, в цензурный комитет, к председателю главного управления по делам печати - разъяснял, доказывал... В большинстве случаев хлопоты эти увенчались успехом, в противном же случае приходилось уменьшать объем номера...» [ДостоЕВский 1994: 420].

Еще одной интересной цитатой является письмо уже самого Ратынского к Достоевскому, где он жалуется на излишнюю назойливость посыльного: «Сегодня ночью в 12 часов пришел рассыльный из типографии Оболенского, достучался до моих дверей и требовал настоятельно у моего человека, чтобы меня разбудили для просмотра последних корректурных листов Вашего «Дневника». Человек мой его не послушал и хорошо сделал, потому что с воскресенья я чувствую себя нездоровым. Сегодня утром, в ту минуту, когда я шел в церковь, этот 
же рассыльный явился за корректурою. Я сказал ему, чтобы он не приходил ранее сегодняшнего вечера и не осмеливался в другой раз стучать по ночам в дверь моей квартиры. Мне кажется, что он назойлив, потому что - франт: в бекеше с бобровым воротником и модных сапогах...» [Волгин 1970: 109].

Первым серьезным столкновением Достоевского и цензуры можно считать издание июльско-августовского выпуска за 1876 год. Возвращая корректуру главки «На каком языке говорить будущему столпу своей родины?», Ратынский пишет: «Будьте так добры, многоуважаемый Федор Михайлович, исключите из этой корректуры выражения «отцы отечества» и «похабность». Сия последняя, пожалуй, сойдет, но «отцы отечества», начинающиеся с тайных советников, под цензурою немыслимы. Вы легко найдете другое, соответствующее выражение, не испортив прекрасной Вашей мысли, а меня этим чувствительно обяжете. Вместе «отцы отечества» нельзя ли хоть «столпы отечества» или что-нибудь в этом роде? На похабность можно махнуть рукою, но и ее несколько смягчить следовало бы. Искренно уважающий Вас Н. Ратынский. 27 августа 1876» [Волгин 1970: 110].

Как видно из названия главки, Достоевский послушал цензора. Изменился и текст: «О, конечно, карьера его не пострадает: все эти - родящиеся с боннами предназначаются своими маменьками непременно в будущие столпы своей родины и имеют претензию думать, что без них нельзя обойтись... Столпом своей родины он, будет, конечно, ему ли не дослужиться». Этим изменением Достоевский, безусловно, смягчил политический и социальный подтекст. Интересна речь Ратынского: это никак не похоже на менторский, приказной канцелярский тон хладнокровного и равнодушного человека - цензор практически просит, мягко замечает о том, что необходимо подправить и даже предлагает свои варианты, демонстрируя свою вовлеченность и заинтересованность. Он даже идет на уступки, говоря, что слово «похабность» так же не годится, но закрывает на это глаза.

Обратимся к еще одному факту цензурного вмешательства Н. Ратынского. В январском выпуске «Дневника писателя» за 1877 год Достоевский, реагируя на статью, характеризующую движение петрашевцев, считает нужным внести свои правки и дополнения в понимание этого общества, членом которого когда-то сам являлся, и печатает главу «Старина о петрашевцах». Глава эта полностью запрещается с пометкой «воспоминания о бывших тайнах и заговорах неуместны». Достоевский идет к Ратынскому объясниться, желая вступиться за опальную главу и сохранить ее для «Дневника». Из писем мы делаем вывод, что имел место неприятный разговор «на повышенных тонах». Н.А. Ратынский объясняется перед писателем письмом, в котором уверяет в своей расположенности и доброжелательных помыслах. Необходимо отметить, что Н.А. Ратынский в молодости был лично знаком с М. Петрашевским и даже привлекался к допросам по делу петрашевцев. Однако если Достоевский был наречен государственным преступником и отправился в Сибирь на каторгу, то с Ратынского подозрения были сняты, и он даже выстроил себе карьеру госслужащего. И вот спустя годы к тайному советнику Ратынскому поступает на цензурирование 
текст «Старина о петрашевцах». Разумеется, Ратынский, человек уже подозреваемый в революционных настроениях, а ныне чиновник, верный государственной службе, не мог допустить подобную главу к печати. Скандал мог произойти из-за одного названия, а за ним - новое подозрение в заговоре: бывшего государственного преступника Достоевского и тайного советника Ратынского. Возможно, в том числе по этой причине Ратынский все в том же письме предлагает Достоевскому сменить цензора, «который не так близко к сердцу принимал бы подобные столкновения».

Подводя итог, необходимо отметить, что вопрос изучения личности Николая Антоновича Ратынского, заметно повлиявшего на литературный процесс в отечественной публицистике второй половины XIX века, подлежит дальнейшему изучению. Исходя же из вышеприведенных фактов можно сделать вывод, что Ратынский подходил к исполнению своих цензурных обязанностей исключительно с точки зрения профессионализма. Это был честный, интеллигентный, умный человек, добросовестно занимавший свой пост и качественно выполнявший свою работу. Николай Ратынский является отличным примером профессионального, компетентного и вежливого цензора, стремившегося к компромиссу, пытаясь так или иначе помочь талантливым литераторам, своими действиями заметно повлияв на литературный процесс второй половины XIX века в России.

\section{Литература}

БЕлодУБРОвский 1985: Белодубровский Е.Б. К датировке записки Некрасова к Н.А. Ратынскому// Русская литература, 1985/1: 237-238.

Волгин 1970: Волгин И.Л. Достоевский и царская цензура: К истории издания «Дневника писателя» // Русская литература. 1970/4: 106-120.

ДЕмчЕнко 2012: Демченко А.А. «Отечественные записки» и цензура 1840 1880-х гг. // Известия ВГПУ. 2012/4: 119-124.

ДоСтОЕВСКАЯ 1987: Достоевская А. Г. Воспоминания, Москва: Художественная литература. ДостОЕВСКИй 1877: Достоевский Ф.М. Письма. // Автограф. ГЛМ. ОФ 5709.

ДостоЕВСКИй 1964: Достоевский в воспоминаниях современников. Москва, Т. 2.

ДостоЕВСКИй 1994: Достоевский Ф.М. Собрание сочинений в 15 томах. Санкт-Петербург: Наука, Т. 13.

НЕКРАСОВ 1949: Некрасов Н.А. ІІ / АН СССР. Ин-т рус лит. (Пушкин. Дом). - Москва: Издательство АН СССР.

ОПочинин 1928: Опочинин Е.Н. Воспоминания. Князь П.П. Вяземский http://dugward.ru/library/vyazemskiy/opochinin_vyazemskiy.html (Дата доступа: 08.07.2018).

РЕйтБЛАт 2016: Рейтблат, А.И. Фаддей Венедиктович Булгарин: идеолог, журналист, консультант секретной полиции: Статьи и материалы. Москва: Новое литературное обозрение.

САЛтыКОВ-ЩЕДРИН 1880: Салтыков-Щедрин. Письма. 1880. // ГБЛ, ф. 576, карт. 2, №21.

САЛтыКОв-ЩЕдРИн 1923: Салтыков, К.М. Интимный Щедрин. М.; П.: Государственное издательство. 
САлТЫКОВ-ЩЕдРин 1976: Салтыков-Щедрин М.Е. Письма. 492. Н. А. Некрасову. 3 сентября 1876. Петербург // М.Е. Салтыков-Щедрин. Собрание сочинений в 20 томах. Москва: Художественная литература, 1976. Т. 19. Кн. 1.

САЛтыков-ЩЕдРИН 1977: Салтыков-Щедрин М.Е. Письма. 1423. Н. А. Белоголовому. 25 сентября 1887. Петербург // М.Е. Салтыков-Щедрин. Собрание сочинений в 20 томах. Москва: Художественная литература, 1977. Т. 20.

ТрохинА и др. 1998: Трохина О., Корчева Л., Воробьев А. Орловские губернаторы / Под общей редакцией И. Мосякина. Орел: Вешние воды.

ФЕт 1983: Фет А.А. Воспоминания / Предисл. Д. Благого. Сост. и прим. А. Тархова. Москва: Правда.

Дмитрий МАЗАЛЕВСКИЙ

Pushkin State Russian Language Institute

Moscow, Russia mazalevsky413@gmail.com 